\title{
“En híbrida mezcolanza”: Exile and Anxiety in Alirio Díaz Guerra's Lucas Guevara
}

\section{Jeff Browitt \\ University of Technology, Sydney}

In 1914, Lucas Guevara, a novel of Latin American immigration written by the Colombian exile, Alirio Díaz Guerra, was first published in New York. It remained forgotten until Nicolás Kanellos, the Director of the Recovering the US Hispanic Literary Heritage Project, unearthed a copy of the first edition in a New York public library in 1976. The novel has since been claimed as the earliest about Latin American immigration to the USA written in Spanish. This fact alone merits its study. But the novel is also unique in that typically it is literature by Puerto Ricans, Mexicans and Cubans, and not a Colombian, that is most associated with the Latin American migrant experience. Arte Público Press published the novel for a second time in 2001. The second edition comes complete with a critical-biographical introduction by Kanellos and Imra Liz Hernández, which presents the novel as the precursor of a developing genre of a certain type of Latin American immigrant literature centred on the naïve verde (greenhorn) who arrives in the USA inspired by the opportunities that the metropolis supposedly affords. The protagonist nevertheless suffers a series of misfortunes because of the inability to adapt to or withstand the hostility of the new culture. The price to be paid for this failure is to return home, or to remain and die. ${ }^{1}$ Díaz Guerra portrays such a hapless figure in Lucas Guevara. Though on the level of overt content the novel is a stereotypical denunciation of a supposedly amoral and corrupting US society, what is fascinating is the insight it provides, through the narrative voice and the authorial presence, into the anxieties secular modernity occasioned for a certain kind of exilic subjectivity (masculine, heterosexual, Spanish American, elite, morally conservative), which struggled to adjust to the cultural in-between-ness induced by nostalgic longings for an idealized memory of homeland in the midst of an alienating host culture.

Díaz Guerra was born in Colombia in 1862 into a prominent family of politicians, his father being the federal treasurer for the Liberal Party government at one stage. He was educated at the Universidad Nacional de Colombia en Bogotá, firstly in letters and then in medicine. He began to write and publish poetry at an early age. Like other Hispanic letrados, ${ }^{2}$ Díaz Guerra early on showed a dual liking for poetry and politics. In 1884 ,

\footnotetext{
${ }^{1}$ Kanellos and Hernández (2001, p. iv) list several other novels among which Lucas Guevara seems to be the first: Conrado Espinosa, El sol de Texas (1927); Daniel Venegas, Las aventuras de Don Chipote (1928); Gustavo de Alemán Bolaños, La factoría (1925), Guillermo Cotto-Thorner, Trópico de Manhattan (1951); René Marqués, La carreta (1952); Iván Acosta, El súper (1971); Mario Bencastro, Odisea del Norte (1999); Roberto Quesada, The Big Banana (1999) and Nunca entres por Miami (2002). ${ }^{2}$ A letrado was a patrician intellectual with a cosmopolitan and universalizing worldview whose credentials were based on the social authority of the scribal culture of "letters," which straddled law, literature, politics and history, and which was crucially linked to nationalism and state-building in nineteenth-century Latin America
} 
when he was barely 22 , he founded a newspaper, El Liberal, in opposition to the then conservative Colombian administration. Shortly after, the Liberals rose up in armed revolt against the proposed constitutional changes by the ruling Conservative Party. The Liberals were defeated and in 1885 Díaz Guerra was obliged to flee, penniless, to Venezuela where he would spend the next ten years in exile. Because of his social and political standing in Colombia and because of a Liberal-minded government in power in Venezuela, he was soon able to secure employment, firstly as Surgeon General of the Central Railroad, subsequently as private secretary to the then Venezuelan president, Joaquín Crespo. When Crespo was deposed by the political opposition, he was still able to find employment as Director of Public Education, and when Crespo returned for a second term, Díaz Guerra was appointed Secretary of State. He married the daughter of a well-to-do family and in between work and family duties, continued to publish poetry, but also, and importantly, inflammatory articles against the conservative Colombian government of the day.

In 1895, Díaz Guerra wrote a series of secret letters on government letterhead inciting a Liberal revolution against the then Colombian government. The letters, which also implicated President Crespo in the "Colombian revolutionary cause," were handed over by a traitorous co-conspirator to a Panamanian newspaper for publication. Due to the acute embarrassment this occasioned the Venezuelan government and in order to avoid a major diplomatic incident, Díaz Guerra was forced to go into exile once more (Díaz Guerra 1933: 223-36). The alternative was to remain and probably face a firing squad. He sailed to New York in 1895, the same year that José Martí, at the time perhaps the most prominent of Latin American political exiles, left to fight (and soon die) against the Spanish colonial government in Cuba. Little is known of Díaz Guerra's early years in New York except that he was Director of the General Office of the Republic of Colombia for three years not long after his arrival and that he travelled extensively in Europe before returning to the USA to take up employment as an international sales representative for Sharp and Dohme, a pharmaceutical company. Somewhere during this period he also made the transition from exile to confirmed immigrant. Except for international travels for Sharp \& Dohme, including occasional visits to Latin America, Díaz Guerra spent the rest of his life in New York until sometime in the late 1930s when he died, though exact details are unknown. During his time in New York he was a foreign correspondent for several Latin American newspapers and published a few more volumes of poetry and a couple of novels. Only one novel has survived, Lucas Guevara, which was published after he had been in the city for almost 20 years.

Not long before he died and at the instigation of Venezuelan friends, Díaz Guerra wrote a memoir of his life in Venezuela (Diez años en Venezuela, 1933), which, though post-dating Lucas Guevara, was written in an almost archaic, florid, romantic style. In the opening chapter that relates his ignoble flight from Colombia to Caracas in a French steamboat, Díaz Guerra uncannily echoes the plot of his novel 20 years earlier and its denouement in the suicide of its main character, Lucas Guevara. He recalls his depressed state at the time of his forced exile:

Only someone born, brought up and educated in a social sphere of comfort and decency ... is capable of understanding how humanity can be reduced to the category of a beast without, by beneficent providence, either losing his mind or 
resorting to the solution of the desperate - suicide. (Díaz Guerra 1933: 10) ${ }^{3}$

Shortly after his arrival in Venezuela, Díaz Guerra was immediately invited into the circles of high print culture as a member of the Venezuelan Academy of Language and by having his poems published in the most popular daily newspaper. His literary success was due to his ability to craft verse in the ornate style of Spanish and Latin American romanticism, singing the praises of the great men and deeds of the Venezuelan republic or writing hymns to filial piety, chaste virgins or religious devotion: "Christian faith/you are the blessed one/the magical flower of paternal dwelling/which in the rough squalls of life/conserves its verdure and fragrance" (54). But literary success was no doubt also due to the social and political capital that elite credentials afforded, a capital that was transferable across national boundaries in the Americas to a social and cultural network of Creole pan-Latinity. Díaz Guerra was therefore soon able to ingratiate himself with the Liberal Venezuelan power elite, which ensured a succession of government postings. The Venezuelan memoirs have only minor historical interest, but for the purposes of this reading of his novel, what is important to note is the way Díaz Guerra carefully constructs his own persona: Christian, virtuous, maritally faithful, noble, loyal, altruistic, nationalistic, and so forth. These values embedded in his literary and autobiographical writings provide the prism through which he would subsequently come to judge the supposed failings of society and culture in New York as portrayed in his novel.

Lucas Guevara follows the trajectory of a young man (Lucas Guevara) from a middleclass family who arrives in New York from Santa Catalina, a rural town in a South or Central American country. He has a stipend to support him while he studies, the idea being that he will return with some sort of technological training that will be put to good use in his own country at some future date. The specific country is never named, but there are clues to suggest it is Colombia, though this has no real bearing on the structure of the novel or its interpretation. The novel's theme is common to nineteenth-century bildungsroman in which a young man sets out for the big city in search of success and fulfilment, but only finds disillusion. There is, however, no self-development or overcoming of obstacles, no final triumph. Through the novel we get a feel for the texture of daily experience in New York in the first decade of the twentieth century and the cultural consequences of modern capitalism: the metropolis's feverish tempo and anonymous encounters, the play of desires unleashed by consumerism and secularism, the exploitation of the newly-arrived immigrants, the Bowery as representative of the human detritus of capitalist modernity, and a skyline dominated by the wonders of modern technology, including the Brooklyn Bridge and the aerial railways, and that symbol of promise, The Statue of Liberty.

Soon after his arrival, Lucas is met by Jacinto Peñuela, a street-wise New York Latino pícaro, who seems to specialize in preying on the ingenuous. Peñuela is not so much a swindler as a sponger who attaches himself as guide and counsellor to verdes, shows them around the city and gets them to pay for everything. Peñuela takes Lucas to meet the New York businessmen from Lucas's home country to whom Lucas must present his letters of introduction, the businessmen agreeing to monitor Lucas's progress

${ }^{3}$ Translations into English throughout this chapter are my own. 
as well as his monthly allowance. Peñuela also directs Lucas to a boarding house, to the chagrin of Guevara's businessmen compatriots, equally versed in exploiting the naïve. These businessmen, like Peñuela, make money on the side directing novitiates like Guevara to stores, bars, and boarding houses from which a kickback is to be gained. There is a very real sociological background to this story since at least forty percent of the New York's inhabitants were immigrants during the period of the novel and boarding houses and tenement slums were the principal housing options available.

Peñuela gradually introduces Lucas to New York life around the Lower East Side, famously the home to many a generation of immigrants, where he is quickly enthused by New York's women, especially the "siren temptresses of the Bowery" (Díaz Guerra 2001: 29). He is soon having affairs with the women at the boarding house, frequenting bars and visiting prostitutes and generally dissipating his energies in nights of debauchery. New York, or more particularly in the novel, the Lower East Side, thus becomes a moral landscape against which Lucas's misfortunes are played out. He has a run-in with his first boarding-house proprietor and has to move to another lodging. He has a brief and disastrous (forced) marriage, manages to spend his monthly stipend too quickly, has a falling out with his father's acquaintances because of his irresponsible behaviour, is briefly jailed for hurling a vase in the face of one of them in a fit if rage, and is bailed out by a widow who, finding him attractive, invites him to live with her as a kept man. When his stipend is suspended, he soon begins to take on a role similar to Peñuela, preying on newly arrived Latin American immigrants and visitors keen to know the Lower East Side. He is eventually thrown out by the widow and progressively slides into poverty and depression, living the life of the most destitute and homeless in the big metropolis, falling victim to all kinds of abuse and exploitation. He works a summer on Coney Island, but finds himself once again on the street when the vacation season finishes. At the end, broke and disillusioned, he commits suicide by throwing himself of the Brooklyn Bridge. Though he is the main protagonist whose tragic suicide is supposed to command our attention as readers, by the end of the novel his self-indulgent behaviour leaves the reader feeling unsympathetic. Whatever the shortcomings of the novel on the level of content, it seems to want to function as a condensed allegory of the indignities and lost dreams suffered by Latin Americans who arrive in the United States, principally men who feel themselves symbolically emasculated in what is portrayed as a hostile, godless, exploitative and racist Anglo-American culture. Nevertheless, there are limits to this allegorical dimension, most notably in terms of the class position of both the narrative voice and the protagonist. I will return to this issue in the conclusion.

In their critical introduction to the novel, Kanellos and Hernández point out how Lucas Guevara is not only the earliest known novel of immigration written in Spanish, but also that it is the precursor in structure and formula of many novels to follow throughout the twentieth century, both in Spanish and English, which deal with a similar theme: the disingenuous Latin American immigrant, victim of all kinds of abuse in the United States, including at the hands of Anglo-American women, who personify the avarice and treachery of Anglo-Saxon culture and civilization. In the process, such novels establish a counter-myth in Spanish, which is:

the opposite of the American Dream ... the opposite of what occurs in the novel of immigration in English, which upholds that dream as the essence of the American 
bildungsroman, whose most clear examples are The American by Howard Fast, Studs Lonigan by James Farell, America, America by Elia Kazan and Call It Sleep by Henry Roth. In fact Hispanics themselves who write their ethnic autobiographies in English scrupulously follow this bildungsroman of the American Dream: Oscar Hijuelos, Edward Rivera, Esmeralda Santiago, Víctor Villaseñor, etc. (Kanellos and Hernández 2001: iv-v).

Nevertheless, Kanellos and Hernández highlight the simplistic binary on which Lucas Guevara is based: "New York is Babylon while Santa Catalina is an Eden; New York is the seat of corruption and Santa Catalina, though poor and backward, is the realm of purity and innocence." They also emphasize the novel's overt "misogynist vision of American women" (2001: vii, x), who devour incautious immigrant men. Metropolitan culture and its materialism and licentiousness are thus strongly contrasted with the supposed more authentic and more worthy spiritual and cultural values embodied in the immigrant's own "Hispanic" nation. ${ }^{1}$ Hence the moral to be drawn from such tales for Latin American readers is that "they should remain at home and not allow themselves to be deceived by the myth of the USA, because the Metropolis, instead of being the path to perfection, is the path to destruction" (xv).

Kanellos and Hérnandez's critical introduction to the second edition of Lucas Guevara performs a valuable service in rescuing the book from oblivion and provides a highly commendable, critical introduction. Yet it fails to sufficiently separate out the narrative voice from an analysis of the overt content (the storyline), missing an opportunity to engage with the contradictory tensions in the moral centre and filter through which this overt content is framed, interpreted and ideologised. Lucas Guevara may very well be received by the average or "non-intellectual" reader on the level of manifest content - the ideological "message" Kanellos and Hernández wish to extract about the rejection of Anglo-American culture and the preservation of authentic or higher, Hispanic moral values. But there is also a much deeper conflict at work in the stance of the narrative voice and by implication the implied author: the attempt to maintain a stable Latino masculinity in face of the secularising and emasculating metropolis. For instance, though Kanellos and Hernández call attention to the blatant misogyny of the novel, they do not investigate what is clearly an unconscious and ambivalent attitude on the part of the narrative voice towards sexuality, nor the class and racial anxieties unleashed by social mixing in the modern metropolis.

Though Lucas Guevara is a lachrymose, stereotypical and conventional denunciation of the supposed evils of an amoral US society, a closer reading leads away from a concentration on the main character and the storyline or récit: the least interesting personage in the novel is Lucas Guevara himself. As opposed to most other Latino immigrants from the under-classes doing it tough on the Lower East Side, Guevara lives off a stipend and has a semi-comfortable existence to return to if he so chooses. He is far removed from the fate of those hundreds of thousands of poverty-stricken immigrants and exile who were flooding into New York at the same time. Nor does he arouse our sympathy because of his self-indulgence and inability to learn from bitter experience: he seems constitutionally incapable of resisting problematic relationships with women, though he seems perfectly capable of absorbing other lessons of survival in the slums imparted by the street-wise Peñuela; in short, he is too much of a cardboard figure to be 
believable. At the end of the novel the reader herself would be quite justified in pushing him off the Brooklyn Bridge. Therefore, though the novel can no doubt be read as a cautionary tale of moral ruination within the context of an underlying Christian allegory, there is a certain kind of farcical quality to the story.

On a deeper level, however, a picture emerges of Díaz Guerra himself as a displaced, disenchanted intellectual exile who suffers an acute cultural and class anxiety in the transition from a patrician Arcadia to the metropolitan culture of New York, thus his ambivalent experience of exile/immigration. The near obsessive concentration on sexual activity and temptation further highlights this dissonance between New York and an idealized image of a pre-lapsarian fatherland, an image from which class and racial hierarchies have been expunged conveniently. Through a reading of the narrative voice, and by extension of the implied author, and by juxtaposing the public persona carefully crafted through Díaz Guerra's memoirs of his ten-year sojourn in Venezuela, we witness his difficult coming to terms with a highly-charged New York society. He is not simply subject to the problems of an exile attempting to insert himself in a new society at the level to which he is accustomed (educated, middle-class, morally pious). He is also subject to the influence of sexual liberation brought on by secular modernity and the close proximity of volatile, eroticized bodies on the over-crowded Lower East Side of New York, the scene of the novel and Díaz Guerra's own point of entry into the USA.

It is significant that the attacks on US society are carried out by the narrative voice and not by the voice of the protagonist. Because this narrative voice is an ostensibly reliable voice of authority and omniscience, and because there is no countervailing discourse to contradict or undermine its perspective, it may be assumed that certain elements in the narrative perspective are consonant with that of the implied author. This implied presence expresses a kind of "surplus," an excess that appears to escape conscious, authorial control, unaware of its own Freudian investments in the story. That discordant surplus centres on three recognizable thematic anxieties, of which the narrator/implied author seems only partially aware: first, an obsessive concern with female bodies, sexual promiscuity and uncontrollable desires (primarily blamed on stereotypical, libertine Anglo-American women); second, an acute class, racial and cultural anxiety in relation to the social and cultural mixing in the secular, rapidly modernizing metropolis; and third, an ambivalent appreciation of technological modernity. It is through narrative commentary and focalization that a picture emerges, then, of a writer who initially lived a difficult relationship to New York, the tensions and negotiations of which cannot simply be banished at the end by a romanticized scene of suicide. This dissonance in the narrative perspective paradoxically makes Lucas Guevara an open text, in spite of its stereotypical plot.

How, then, is narrative perspective fashioned in the novel? The narrator establishes himself very early on as cultured via references to high European culture, as when, for instance, he names the operas from which the street musicians in the neighbourhood form their repertoire: "wandering musicians who, with the greatest audacity, destroy fragments of opera and assail, in particular, Trovador, Traviata, Rigoletto y La Fille de Madame Angot" (Díaz Guerra 2001: 35); so too his reference to Guevara's wife's "letters of emotional outpouring, more eloquent, moving and passionate than all the epistles of Lord Chesterfield to his son" (63). These and similar nods to music and literature create an image of the cultured, ideal reader Díaz Guerra may have had in 
mind, and sets the novel apart from the more desperate tales of those who did not arrive in the USA with a stipend and had to endure untold hardships from the first moment of arrival. The dense use of figurative language also distances the narrator's voice from the main character and makes implied links with the knowing reader, since such elegant prose style is not the language of Lucas Guevara or the common, immigrant man in the street. Who, then, is the ideal reader? Most likely fellow middle- or upper-middle-class, cultured and morally pious Latin Americans, either in New York or would-be immigrants at home, who have marked their class distance from both their compatriots and Anglo-US culture.

\section{'Lewd and heaving breasts'}

A key characteristic of the narrative perspective is the repeated concern, expressed with irony and parodic humour, with sexuality and temptation and from a decidedly male, heterosexual perspective. Early on we have a characteristic, ironic aside when the narrator describes the belongings that Guevara packs for his trip to the USA, including "few clothes, but abundant scapularies, rosaries and other pious odds and ends, articles that ... save souls from the temptations of Satan" (7). This seems none other than a mocking reference to what is to come - the precise inability of the protagonist to avoid such temptations. When Jacinto Peñuela takes Guevara to a sleazy cabaret, the narrator describes a scene in which "around hundreds of small tables, men and women of all age and condition gathered in crude and licentious mix, repugnant even to the least observant gaze" (73). The narrator describes the women as made up with lipstick, "from the languidly pallid to the most intense; bare backs, lewd and heaving breasts, naked arms" (73); and focalizes through the consciousness of Guevara, who "couldn't understand how those female heads, sporting hats adorned with flowers and feathers, those busts covered with ribbons and lace, those waists wrapped in velvet and silk, could be bought with money and at cheap prices" (75). This is not exactly fictional verisimilitude, especially given the description of the bar that precedes this meditation and given that the sons of well-to-do estate owners and other ruling-class males in Latin America up to this period have historically had a reputation for availing themselves of prostitutes. Furthermore, the description of the bar and the females is eroticized by the narrator, not Guevara, which leads the reader to conjecture about the implied author's own proclivities for the wellcontoured female body in the metropolis. This impression of the implied author's own erotic investments in the novel is reinforced by the narrator's descriptions of the rituals and financial transactions of prostitution in the cabarets and small hotels (72-78) as well of the interior and the workers of a brothel (97-104), the minute details of which seem nothing short of a knowledge born of experience. Such knowledge may derive from the author himself having frequented the bars and bordellos of the Lower East Side, or perhaps it derives from Díaz Guerra having possibly worked as an unregistered immigrant physician in such an industry, though there is no evidence to support the latter claim.

Sexuality, especially its irrepressibleness, is a constant throughout the novel. In a humorous interlude, the narrator mocks a pair of self-important Latin American financiers. Peñuela, feeling sorry for Lucas, who by this stage is penniless and in gaol for assault, asks a couple of business acquaintances and friends of Lucas's family if they 
might help out. His visit becomes an occasion to send up the pompous Christian morality of the bankers as they hold forth on family values. Remember, we are reminded by the narrator, and Kanellos and Hernández in the introduction, that counterpoised to the licentiousness of US culture are more traditional, conservative "Hispanic" values embodied in the native language and culture, in the family, Catholicism, female chastity, and so forth:

Don Nicomedes, with the characteristic eloquence his admirers claim he possesses, expounded his theories of marriage and ended by advising Peñuela to try and establish a home, for this is the foundation of morality, the source of love and peace and a positive base for the economy. Don Patrocinio couldn't avoid adding his five cents worth to his companion's luminous and civilizing exposition, limited, fortunately, to the passionate advice that in case he should have a family, that he not allow his children, least of all his daughters, read novels, for there exists no book of that nature that does not contain love affairs, which would be the equivalent of exposing virgin imaginations to the serpent of lust. (170)

This is Díaz Guerra at his ironic and self-mocking best, not only sending up the bankers' sham moralizing, but also gesturing tongue in cheek to his own novel, replete with sexual activity. Nor is the narrator averse to indulging in a bit of ribald Latino masculine fantasy and stereotyping when he describes how female boarding house owners are attracted to Latin men: "certain skins toasted by the sun of the tropics, certain black and somnolent eyes and certain anatomical traits, not common in the races of the North, generally impress the Eves with alabaster skin, blue eyes and blonde hair; probably a question of contrast" (196).

\section{A Latino flâneur in secular modernity}

Much of this satirical humour in Lucas Guevara is consonant with the picaresque style in Spanish literature. It is significant that Díaz Guerra uses many of the tropes of the picaresque form: the naïve life story; the initiation of the protagonist into the corrupt underworld of vice; a genuine picaresque character in the person of Peñuela; and social satire aimed at the deceitfulness and hypocrisy of a variety of class representatives of the pious and the powerful who prey on the most vulnerable, and so forth. Díaz Guerra also displays a genuine talent for such caricature and satire underpinned by a moral vision, a hallmark of the best picaresque novelists. But so too does the novel diverge significantly from the picaresque form: it does not present the life story of a low-born central character who manages to climb the social ladder, who is transformed through self-knowledge; that is, there is no happy ending. Furthermore, the protagonist is not morally indifferent, but rather US society is portrayed as such. As opposed to José Zorilla's Don Juan Tenorio (1844), for instance, echoes of which abound in the novel, the protagonist is portrayed as victim of deceitful women, and not the reverse. In fact the novel in many ways is more Dickensian than anything else, in its contrast between the bourgeois gentility of the narrative perspective and the portrayal of the daily grind of lower-class survival, in its portrayal of the hypocrisy and corruption of a society supposedly dominated by utilitarian 
industrialism, by materialistic values, in its contrast between moral pretensions and actual behaviour. But more importantly for the purposes of this essay, what is obviously under threat throughout the novel, and by extension in the authorial stance, is a hitherto seemingly stable, Latino male subjectivity, now made vulnerable by an unfamiliar cultural and moral environment - the secular, modernizing metropolis and its devouring women and its technology, symbolized respectively by two key landmarks: the Statue of Liberty (Libertinism); and the Brooklyn Bridge (technological progress).

This hitherto stable, Creole elite sense of self is also threatened by a loss of legislative hegemony by the socio-economic modernisation of society. Chapter 37 is a set piece: a mini-chronicle of Coney Island, a descriptive break in the narrative progression similar to the meditation on the Brooklyn Bridge, the Bowery, boarding houses, New York reporters, and so forth. Like Martí's Coney Island crónica, it is an ambivalent portrait of the incipient culture industries and the massification and democratization of "bad taste," as well as social and cultural mixing. One particular scene is significant for the narrative focus on the "brazen" bodies at play on the beach:

In Coney Island ... there is an agitated abandon and fearful competition, forming an indescribable labyrinth, a heterogeneous group, a drawing without profile, a figure without contour, a formless agglomeration that injures the senses, delights, tires, makes one dizzy, annoyed and crazy ... [on the beach] the bathers, that is to say, the thousands of Adams and Eves of all classes and standings, romp for hours in the waves or writhe and rollick even more daringly on the sand, with a shamelessness capable of offending even the most trivial precepts of chastity, with their wet shirts stuck to their bodies and their naked arms and calves ... showing off provocative shapes. (262)

This is publicly-licensed sensuality, a phenomenon of the late nineteenth and early twentieth century in New York, which, along with cabaret culture, provided an avenue of release for an urban culture in rapid transformation, a "new consumption, entertainment, sexuality," which, for Lewis Erenberg, culminates in the 1920s. This transformation was particularly vexing for class-conscious cultural conservatives who saw only "cultural decline and urban pathology. The anonymity of city life, in their estimation, produced cultural decay" (Erenberg 1981: xiv).

In Lucas Guevara, such metropolitan urbanization and massification provoke a cultural-nationalist rejection of Anglo-Saxons. There are constant references to the raza [española], a cultural and moral touchstone which seeks too reinforce a perceived hierarchy of values and identity centred on the purported moral superiority of Hispanismo. From early on in the narrative, the panorama that greets the immigrant in New York is described as a "seething mass of people of all races and all customs" (Díaz Guerra 2001: 9); New York's population is variously described throughout the novel as the "multitudes," "the swarming crowd," "a human wave," "the whirlwind," and so forth. The anxiety at losing one's individuality within the crowd is expressed in a striking description of the city, in which Díaz Guerra unwittingly presages José Eustasio Rivera's renowned 1924 novel, La vorágine (The Vortex), where the incautious and adventurous male is overwhelmed and ultimately destroyed by the Colombian jungle. Here, it is the concrete jungle, the burgeoning metropolis that threatens masculine individuality: 
the future opened its maw and threatened to devour him ... he found himself in the entrails of New York, the frightful vortex that envelops everything, where the value of individuals is measured by the amount of money in their pockets; where nobody knows anybody; where the beggar is pursued with more vigour than the criminal; where every job, no matter how insignificant, has thousands of candidates who struggle and submit themselves to all kinds of indignity in order to win it ... where crammed into unhealthy buildings, succumb hundreds of people disinherited by luck, hungry and cold in the winter, starving and asphyxiated in summer. Thus he regarded New York, that immense, heterogeneous and hybrid mass, seat of all cultures, support of all customs, center of all vices, ocean of all passions, market of honor, barrel in which all ambitions are amassed, desert in which all souls are sterilized and with the heat of mercantile fever, all hearts are petrified. (143)

The anxieties of both the protagonist and the narrator in the face of modern life are remarkably similar to Georg Simmel's attempts to come to terms with modern urban life in his classic essay, "The Metropolis and Mental Life," written at the turn of the nineteenth century (2002 [1903]). Simmel stresses the overwhelming impact the modern metropolis and its ethos, proscribed by the money economy, has on the individual. The metropolis, as the "locale of freedom" and the "seat of cosmopolitanism," offers the possibility of anonymity and independence in comparison to the tightly knit, conformist pressures of the small town; but it also takes the form of an indifferent and unresponsive juggernaut ruled by the logic of exchange value:

Money, with all its colorlessness and its indifferent quality, can become a common denominator of all values, it becomes the frightful leveler - irreparably it hollows out the core of things, their peculiarities, their specific values and their uniqueness and incomparability in a way which is beyond repair. (Simmel 2002:14)

For Simmel, then, the metropolis becomes the theatre of a struggle between the individual and overwhelming social and technological forces:

Here in buildings and in educational institutions, in the wonders and comforts of space-conquering technique, in the formations of social life and in the concrete institutions of the State is to be found such a tremendous richness of crystallizing, de-personalized cultural accomplishments that the personality can, so to speak, scarcely maintain itself in the face of it. (19)

When Guevara is gaoled for assault, the prison cell comes to represent the Lower East Side in concentrated microcosm: "in unruly hybrid mix [en híbrida mezcolanza], irregardless of sex or class, are gathered beings whose misfortune, desperation, hunger and vice have torn them from the bosom of society" (Díaz Guerra 2001: 159). This trope of negative racial and cultural mixing is also utilized to frame Anglo-American women. Chapter 36, for example, is an extraordinary diatribe against the women of New York, a 
negative and sexist description of incipient women's liberation: "the mixture of races, religion, tastes, aspirations, necessities and even languages has made of this woman a disaster" (252).

Whereas references to the raza in Lucas Guevara are clearly cultural and refer to all Latin Americans, nevertheless the novel is also noteworthy for its overt racism against Jews and Chinese, which shades into cultural anxiety, especially faced with the social and cultural mixing for which New York has always been famous. The narrator attacks racism in the US press against individuals of the raza española [Spanish race] (150), but is not averse to perpetuating racial stereotypes himself, as is witness the following passage:

In Lucas's cell, a Chinese laundry owner was held for two or three days. He was accused of seducing a ten-year old girl, a practice to which are particularly addicted the sons of the Celestial Empire who, in spite of their apparent submissive, quiet and respectful temperament, all harbor the most artful tricks for doing away with the innocence of young girls barely out of the cradle, without the police being able, no matter what the effort, to effectively combat such appetites and customs of these sectarians of Confucius. (162-3)

As if this were not enough, the man is described as emitting "a few guttural sounds, like the barking of a dog with a cold" (164). In another context, the description could have been quite humorous, but after the accusations about child molestation, it reinforces the negative and racist stereotype. Given that the ideal reader for a novel written in Spanish was no doubt other Latin Americans, one can only confirm a general attitude in those days by the majority of ethnicities, including Latinos, towards the Chinese of the Lower East Side. The narrative aside echoes the racial and cultural tensions provoked when disparate ethnicities are thrown unforeseen, as it were, into close proximity by misfortune and poverty.

It is easy enough here to draw the obvious conclusion that the narrative point of view is class-conscious, racist and bigoted against non-Latin Americans. But in counterpoint to his criticisms of racism in the New York press, the opportunism of US newspaper reporters (151-7), the atrocious New York slums, especially the Bowery (28-35), New York women (250-6), and mass culture in the form of the Coney Island amusement park (257-63), the narrator also ridicules what he considers the pomposity and backwardness of a parade of Latin American character types to be found around Lower Manhattan, whether it is through the rantings of the bombastic Don Cesareo holding forth about "the shameful spectacle of yet another fratricidal war," which explains why "the great nations, driven by a charitable and civilizing spirit, want to conquer us!" (146); or the criticisms of the Don Juanesque pretensions of Latin American male immigrants who think that it is

a rare woman who can resist their amorous advances once they look into their eyes, though not because they are seduced by youth in bloom, but because they can't help being fascinated by the way they converse by shouting in a strange language, and because each word is accompanied by all manner of gestures in a tireless gymnastics of hands, arms, legs and feet. (222) 
This is a most revealing comment: the narrator has adopted one of the formal prejudices of Anglo-Saxon culture vis-à-vis Latinos: "they" speak in agitated discourse animating their speech with exaggerated bodily movements (still "too close" to Nature). A distance (both cultural and class-bound) is established with respect to the traits and mannerisms of other Latin Americans (perhaps unconsciously signalling Díaz Guerra's own acculturation in the transition from exile to settled immigrant). What is significant here is that, while the novel pretends to function as a cautionary moral, it nevertheless overflows such functional limits and is transformed into a uniformly negative image of Latin Americans - for the narrator there is no redemptive dignity or altruism, save for the chaste virgins of paradise lost.

Even the Latin American political radicals who use New York as a base for their activities feel the heat of the narrator's scorn, as Lucas Guevara also provides an occasion to contrast how Díaz-Guerra deals with the condition of exile, in contrast to the likes of José Martí:

Lucas was honored with invitations to various Hispanic-American clubs, some literary, others political or social, which in general aspired to organize or had organized furious adversaries of Yankee imperialism who imagine, perhaps because of some cultural atavism, that it is enough for a citizen of Santa Catalina to frown such that the government in Washington catches its breath, and that availing himself of inflammatory pamphlets, manages to recruit a few dozen tobacco workers or analogous elements so that in the name of the "Pan American Alliance," the "Circle of Free Nations" or other such titles, swears to defend the privileges of religion and blood, or even of language, for reasons not hard to figure out. (244)

Perhaps the criticism is a direct reference to José Martí, an iconic figure of Latin American resistance to colonialism. Either way, the reference to Cuban and Puerto Rican political activists is quite clear. What is going on? Let us speculate. The image that emerges from such social satire is wholly pessimistic - there are no counter exceptions, no altruistic political gestures by exiled Latin Americans. Díaz Guerra himself was somewhat of a radical in Colombia and was ordered to leave Venezuela for this reason. However, something led to his disillusion, perhaps the perception that political radicals are part of the problem and not the solution, or perhaps through the prism of a long residence in the USA his revolutionary zeal had been tempered.

In spite of this swipe at the likes of José Martí, Díaz Guerra obviously had no compunction in reprising Martí's use of Coney Island to write an exemplary chronicle of mass culture in the novel. ${ }^{4}$ A reading of both Martí's chronicle and the relevant chapter in

\footnotetext{
${ }^{4}$ Martí's chronicle on Coney Island appeared in a Bogotá newspaper, La Pluma, December 3, 1881 (Ramos 2001: 215). Díaz Guerra would have been 19 years old at the time and given his integration into the lettered culture of Colombian journalism and politics (indeed, the founder of the El Liberal newspaper, one imagines he read the chronicle and was suitably impressed.
} 
Lucas Guevara reveals many similarities, especially an abhorrence of mass cultural entertainment, indeed the massification of society in general. Both display a deep ambivalence towards US modernity. As Kanellos and Hernández point out, in Lucas Guevara the "technological marvels of their [US] 'advanced' civilization do away with humanism, dignity and respect. The immigrant is only a beast of burden or 'camel' necessary for the physical construction of this technological marvel" (2001: v-vi). Nor do the parallels with Martí end there. In Divergent Modernities (2001), his magisterial study of the cultural politics of Latin America's nineteenth-century intellectual elites, including their attitudes towards the cultural modernity of the USA, Julio Ramos contends that in spite of Martí's sense of alienation, he stayed in New York, not only in order to have a base from which to prosecute his revolutionary activities, but also to be near a functioning "literary market" (to use Marti's own words, cited in Ramos 2001: 63). Paradoxically, therefore,

The city, in the very movement that it generated such a "crisis," an "alienation," or "exile," is nevertheless the condition of possibility for the intellectual's autonomy from traditional institutions, an autonomy that was indispensable for the modern intellectual (in contrast to the letrado or 'civil' writer). (64)

No doubt Díaz Guerra also took advantage of such autonomy to re-fashion himself, but away from that of the activist letrado towards that of the detached, ironic literato.

\section{Conclusion}

Aside from its uniqueness as the first known novel of Latin American immigration to the USA written in Spanish, Lucas Guevara has sociological value because it is a not only witness to the metropolis of New York in one of its most expansive phases, but also to an incipient women's liberation from traditional sexual roles, which highlights the way secular modernity unshackles both desire and social mobility. Furthermore, it draws attention in almost laboratory fashion to the assault on Latino male subjectivity, at least that of an elite Creole exile-cum-immigrant. Male exiles found themselves living in a society that protected their freedoms of expression and assembly, but which also embodied values alien to supposedly more traditional Latino conceptions of family values, including filial piety, female chastity, and masculinist codes of honour. The life of the Lower East Side in the novel parallels real life both then and now in New York and the USA in general: the desire to assimilate immigrants to the dominant cultural ethos and the immigrant's resistance to, or difficult negotiation of, such homogenizing tendencies. US literature of immigration of this period stands out for its thematisation, at times satirical and critical, of the problems encountered by the minority immigrant and exile (especially Southern Italians, Eastern European Jews, Chinese, and Mexicans), including labour exploitation and racial and cultural discrimination. In face of such hostility, native language and culture and conservative values are doubly asserted and confirmed.

Modern nations-states try to secure the loyalty of their citizens, not only through national education into juridical-rationalistic ideals of civic virtue, but also through integration into a national culture in order to provide a degree of ontological depth to 
national belonging. As Usha Zacharias (2001: 32) insists: "citizenship is a set of cultural and social processes that must be examined in the realm of everyday life ... cultural citizenship differs from legal citizenship in that it underscores the behaviors, discourses, and practices that give meaning to citizenship as lived experience" (emphasis mine). Hence the process of cultural negotiation becomes problematic for immigrants, refugees and exiles who have been socio-culturally formed in different circumstances and retain a shared cultural identity or ethnic belonging that transcends the boundaries of their host national cultures. Cultural contact does not take place in a vacuum, but rather that contact is often already inflected by historical memory, for instance, of colonialism, violence, military domination, coercion, asymmetries of power, class, racial, gender and religious hierarchies, and so forth. These problems of cultural memory and difference are further complicated by a clash of world views formed by different stages of socio-economic development, a particularly vexing issue for adults moving from less-developed countries to the floodlit streets of the capitals of high modernity. Many Latino immigrant populations in the USA, for instance, retain a sense of cultural belonging (typically regional, but also national), which transcends or lives within the more superficial US national cultural apparatus (the rituals of national belonging). The very idea of an immigrant, exile or refugee as proto-fellow citizen starting from a different cultural position, a different cultural heritage, makes integration or acceptance so problematic for both the host citizen and the newly arrived.

Modernity also unlocks what has always been an uneasy and fragile divide between the sexual self and the spiritual self, a divide that seems difficult to bridge within the precepts of orthodox religions. This unresolved tension is often displaced onto convenient scapegoats: licentious women, other cultures, or simply modernity itself. When these tensions are combined with the condition of exile or immigration, they can become volatile, or simply lead to welcome change. Díaz Guerra seems to be one exile that largely made his peace with his adopted country, if not with modern sexuality. This ability to accommodate was no doubt aided by his privileged starting point - the access his patrician upbringing gave him to the social and cultural networks of Spanish-language literary and journalistic print culture and an elite, trans-national Latino cosmopolitanism, and one hierarchised, moreover, along class and racial lines. While he probably arrived in the USA with very little money, Díaz Guerra nonetheless possessed enough class status to obtain work as a correspondent for several Spanish American newspapers, to secure a senior sales position with an international pharmaceutical company, to even act as Director of the Colombian Information Office in New York, evidence that he had largely resolved his differences with the Colombian Conservative government and had been transformed from exile to confirmed immigrant. Thus, even though Lucas Guevara touches on exilic themes of loss, isolation, incarceration, and exploitation as its protagonist descends into social and moral ruin, Díaz Guerra's ethnic and racist profiling of Jews, Chinese, dark-skinned people and Anglo-Saxons and his socially privileged position, distances him (and his fictional, middle-class student protagonist) from the more typical trajectory of the majority of underclass Latino immigrants, exiles, and political refugees who entered the USA over the course of the twentieth century. He belongs, then, to a particular fraction of a displaced, educated Latino Creole elite, and one furthermore with a decidedly conservative cast of mind, nostalgic for the loss of status and legislative hegemony that attached to them within the class and gendered social hierarchies in their 
home countries, a loss that becomes sublimated into the puritanical and overweening moralism of Catholic conservatism.

\section{Works Cited}

Acosta, I. (1982 [1971]) El súper [The Superintendent], Miami: Ediciones Universal. Alemán Bolaños, G. La factoría [The factory] (1925), Guatemala City: Sáchez \& De Guise.

Bencastro, M. (1999) Odisea del Norte [Northern Odyssey], Houston: Arte Público Press. Cotto-Thorner, G. (1951) Trópico de Manhattan [Tropic of Manhattan], San Juan: Puerto Rico.

Díaz Guerra, Alirio (1933) Diez años en Venezuela. Caracas: Editorial Élite. (2001) Lucas Guevara. Intro.N. Kanellos \& I. Hernández, Houston: Arte Público Press

Erenberg, Lewis (1981) Stepping Out: New York Nightlife and the Transformation of American Culture, 1890-1930, Chicago: University of Chicago Press.

Kanellos, Nicolás (unpublished manuscript) "La expresión cultural de los inmigrantes mexicanos en los Estados Unidos, desde el Porfiriato hasta la Depresión".

- (2002) "Panorama de la literatura hispana de los Estados Unidos" en Kanellos, Nicolás et al. (2002) En otra voz: Antología de la literatura hispana de los estados Unidos.

— \& Martell, Helvetia. (2000) Hispanic Periodicals in the United States: Origins to 1960. Houston: Arte Público Press

— \& Hernández, Imra L. "Introducción. Lucas Guevara: La primera novela de inmigración hispana a los Estados Unidos”, en Díaz Guerra, Alirio (2001) Lucas Guevara.

— et al. (2002) En otra voz: Antología de la literatura hispana de los estados Unidos. Houston: Arte Público Press

Kraut, Alan PBS Interviews http://www.pbs.org/fmc/interviews/kraut.htm. Accessed November 3, 2004.

Maffi, Mario. (1995) Gateway to the Promised Land: Ethnic Cultures in New York's Lower East Side. New York \& London: New York University Press

Marqués, R. (1952) La Carreta [The Oxcart], San Juan.

Quesada, R. (1999) The Big Banana, Houston: Arte Público Press.

Quesada, R. (2002) Nunca entres por Miami [Never Through Miami], Mexico: Grijalbo. Pilat, Oliver \& Ransom, Jo (1941) Sodom by the Sea: An Affectionate History of Coney Island, New York: Doubleday

Ramos, Julio (2001) Divergent Modernities: Culture and Politics in Nineteenth-Century Latin America, trans. John D. Blanco, Durham \& London: Duke University Press Rivera, J. E. (1929 [1924]) La vorágine [The Vortex], New York: Editorial Andes. Roskolenko, Harry (1971) The Time That Was Then. The Lower East Side: 1900-1913An Intimate Chronicle, New York: Dial Press.

Sante, Luc. (1991) Low Life: Lures and Snares of Old New York. New York: Farrar, Strauss \& Giroux

Simmel, G. (2002 [1903]) 'The Metropolis and Mental Life' in G. Bridge and S. Watson 
(eds) The Blackwell City Reader, 409-24. London: Blackwell. Venegas, D. (1999 [1928]) Las aventuras de Don Chipote [The Adventures of Don Chipote], Houston: Arte Público Press.

Wolff, Kurt (trans.) The Sociology of Georg Simmel. New York: Free Press, 1950, pp.409-424 